\title{
Engineered Toxin Body Targeting HER2 MT-5111
}

National Cancer Institute

\section{Source}

National Cancer Institute. Engineered Toxin Body Targeting HER2 MT-5111. NCI

Thesaurus. Code C162649.

An engineered toxin body (ETB) composed of a single chain variable fragment (scFv) from an antibody targ eting the human epidermal growth factor receptor 2 (HER2; HER2), fused to the enzymatically active de-immunized, ribosome-inactivating cytotoxic payload Shiga-like toxin-A subunit (SLTA), with potential antineoplastic activity. Upon administration, the ScFv moiety of MT-5111 specifically targets and binds to a distinct epitope on HER2-expressing cells. Upon internalization, the SLTA moiety is released and acts as an $\mathrm{N}$-glycosidase, which binds to and cleaves an adenine nucleobase in the $28 \mathrm{~S}$ RNA component of the 605 subunit of ribosomes and prevents ribosome activity. This inhibits protein synthesis and leads to apoptosis in HER2-expressing tumor cells. HER2, a tumor-associated antigen (TAA), is overexpressed in a variety of tumor cell types. 